\title{
A COMPARATIVE STUDY OF BACTERIOSTATIC ACTIVITY OF SYNTHETIC HYDROXYLATED FLAVONOIDS
}

\author{
Mónica S. Olivella; Valeria E.P. Zarelli; Nora B. Pappano; Nora B. Debattista*
}

Laboratory of Physical-Chemistry. Department of Chemistry, San Luis National University, Chacabuco. San Luis, Argentina

Submitted: August 28, 2000; Returned to authors for corrections: January 17, 2001; Approved: June 28, 2001

\begin{abstract}
Among other properties, flavonoids present a notable bacteriostatic activity. In this paper, minimal inhibitory concentrations (MICs) of 5,7,4'-trihydroxyflavanone (naringenin), 5,7-dihydroxyflavone and 2',4',4trihydroxychalcone (isoliquitirigenin) against Staphylococcus aureus ATCC 25923 were determined and compared to values obtained for other chalcones and flavanones previously investigated. Specific growth rates and MICs were determined by a turbidimetric kinetic method. The observed sequence $\mathrm{MIC}_{\text {flavanone }}$ (inactive) $>\mathrm{MIC}_{7 \text {-hidroxyflavanone }}\left(197.6 \mu \mathrm{gml}^{-1}\right)>\mathrm{MIC}_{5,7,4}$-trihydroxyflavanone $\left(120 \mu \mathrm{gml}^{-1}\right)$ showed that the introduction of an electron donating group (-OH) causes an increase in bioactivity. On the other hand, the comparisons $\operatorname{MIC}_{5,74^{4}-\text {-trihydroxyflavanone }}\left(120 \mu \mathrm{gml}^{-1}\right)>>\operatorname{MIC}_{2,4}{ }^{4}, 4$-trihydroxychalcone $\left(29 \mu \mathrm{gml}^{-1}\right)$ and $\mathrm{MIC}_{5,7 \text {-dihydroxyflavone }}\left(105 \mu \mathrm{gml}^{-1}\right)$ $>>\operatorname{MIC}_{2}, 4^{\prime}$-dihydroxychalcone $\left(28.8 \mu \mathrm{gml}^{-1}\right)$ indicated that the chalcone structure is the most favourable for bacteriostatic activity within the flavonoid family.
\end{abstract}

Key words: flavanone, flavone, chalcone, bacteriostatic activity

\section{INTRODUCTION}

In the last years, flavonoid family members, like chalcones, flavanones and flavones, have gained increasing interest due to their numerous applications and properties. Thus, research and use of these compounds as antioxidants $(2,10,16)$, antimutagenic $(6,7)$ and antibacterial $(1,17)$, as well as their vasodilator effects (9), antiallergic activity (3), antidiabetic effect (15) and antiviral action (8) are very important.

An increase in bacteriostatic action by the introduction of an electron donating group $(-\mathrm{OH})$ in the aromatic $\mathrm{A}$ and B-rings of chalcone has been demonstrated in previous works $(12,14)$. On the other hand, a study on trihydroxylated chalcones suggests that bacteriostatic activity is related to the number and position of hydroxyl groups (4).

In order to elucidate which structure is the most convenient for bacteriostatic action within the flavonoid family, minimal inhibitory concentrations (MICs) of 5,7,4'-trihydroxyflavanone (I), 5,7-dihydroxyflavone (II) and 2',4',4-trihydroxychalcone (III) against Staphylococcus aureus ATCC 25923 were evaluated using a turbidimetric kinetic method (13).

\section{MATERIALS AND METHODS}

\section{Microbial strain}

S. aureus ATCC 25 923, mantained by sucessive subcultures in tripticase soy agar (BBL) at $4^{\circ} \mathrm{C}$ and by liofilization.

\section{Chemicals}

High purity compounds were employed (Sigma 99\%, purity degree): 5,7,4'-trihydroxyflavanone (I) and 5,7-dihydroxyflavone (II). 2',4',4-trihydroxychalcone (III) was prepared by ClaisenSchmidt condensation (5). KOH solution to an equimolar 4hydroxybenzaldehyde and 2,4-dihydroxyacetophenone solution in ethyl acetate:water $(1: 1)$ was added. The reaction mixture was kept at $25^{\circ} \mathrm{C}$ for five days. It was diluted with water and acidified with concentrated $\mathrm{HCl}$. The total solution was treated with ethyl acetate to obtain the desired product and dried with $\mathrm{Na}_{2} \mathrm{SO}_{4}$. This

\footnotetext{
* Corresponding author. Mailing address: Laboratory of Physical-Chemistry. Department of Chemistry, San Luis National University, Chacabuco 917 , 5700. San Luis, Argentina. Fax: (+54) 02652-422644. E-mail: ndeba@unsl.edu.ar
} 
extract was concentrated under reduced pressure at $50^{\circ} \mathrm{C}$ and purified on silica gel and Sephadex LH 20 columns chromatography using benzene and methanol as eluents, respectively. After removal of methanol, the yellow-orange crystalline solid obtained yielded $15 \%$ of the pure product. The compound purity was checked by thin layer chromatography (TLC) (polyamide $11 \mathrm{~F}_{254}$, methanol-acetic acid-water, 90:5:5) and spots on the plate were visualized under UV light. The structure was determined based on the chromatographic and spectroscopic data: Rf 0.174; UV $\lambda \max (\mathrm{MeOH}) \mathrm{nm}: 368 ; 242 ; 205 ;{ }^{1} \mathrm{HNMR}$ and ${ }^{13} \mathrm{CNMR}(4)$.

\section{Culture media}

Nutritive agar (Oxoid); Müller-Hinton broth (Oxoid).

\section{Turbidimetric kinetic method}

A $24 \mathrm{~h}$ culture of S. aureus ATCC 25923 in slant agar was transfered to $30 \mathrm{ml}$ of Müller-Hinton broth and incubated $18 \mathrm{~h}$ at $35^{\circ} \mathrm{C}$ with permanent stirring in order to be used as inoculum. Erlenmeyers containing $100 \mathrm{ml}$ of culture medium with progressive concentrations of the drug to be tested were inoculated with $2 \mathrm{ml}$ of inoculum and stirred in a Rosi 1000 culture chamber at $35^{\circ} \mathrm{C}$ and $200 \mathrm{rpm}$, leaving one without drug as control. Aliquots were extracted at $20 \mathrm{~min}$ intervals during $5 \mathrm{~h}$ and transmittance (T) was registered in a UV-Visible recording spectrophotometer Shimadzu $160 \mathrm{~A}$. The values of T were related with the number cfu.ml ${ }^{-1}(\mathrm{~N})$, through the following expression (14):

$$
\ln \mathrm{N}_{\mathrm{t}}=27.4-10.3 . \mathrm{T}
$$

\section{RESULTS AND DISCUSSION}

The compounds assayed were efficient against $S$. aureus ATCC 25 923. The number of cfu. $\mathrm{ml}^{-1}$ at different times was calculated by the expression of the turbidimetric kinetic method.

Considering the microbial growth law:

$$
\ln \mathrm{N}_{\mathrm{t}}=\ln \mathrm{N}_{\mathrm{o}}+\mu \cdot \mathrm{t}
$$

where t: time in min; $\mathrm{N}_{\mathrm{o}}$ : cfu. $\mathrm{ml}^{-1}$ for $\mathrm{t}=0 ; \mathrm{N}_{\mathrm{t}}: \mathrm{cfu}^{\mathrm{ml}} \mathrm{ml}^{-1}$ for a time $t ; \mu$ : specific growth rate in $\min ^{-1}$, values for $S$. aureus specific growth rates in media with progressive drug concentrations were obtained from the $\ln \mathrm{N}_{\mathrm{t}}$ vs t plot during exponential growth phase. Results of growth of $S$. aureus in presence of 2',4',4 - trihydroxychalcone are shown in Fig. 2.

Table 1 exhibits values for the microbial specific growth rates and the drug concentrations added to the culture media.

The obtained results were interpreted satisfactorily by means of the bacteriostatic inhibition mechanism previously proposed (11). Thus, the variation of the specific growth rate $(\mu)$ with the drug concentration follows the relation

$$
\mu=\mu_{\mathrm{T}}-\mathrm{k} . \mathrm{C}
$$

where, $\mu$ : specific growth rate $\left(\mathrm{min}^{-1}\right) ; \mu_{\mathrm{T}}$ : specific growth rate in medium without drug $\left(\mathrm{min}^{-1}\right)$ (control); $\mathrm{k}$ : specific inhibition rate (ml. $\left.\mu \mathrm{g}^{-1}, \mathrm{~min}^{-1}\right)$; C: drug concentration $\left(\mu \mathrm{g} \cdot \mathrm{ml}^{-1}\right)$.

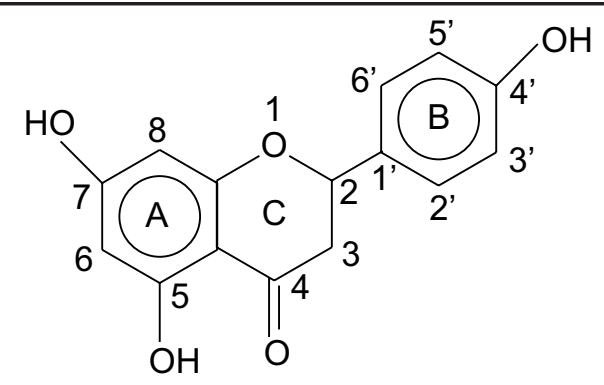

5,7,4'-trihydroxiflavanone (I)<smiles>O=c1cc(-c2ccccc2)oc2cc(O)cc(O)c12</smiles>

5,7-dihydroxyflavone (II)

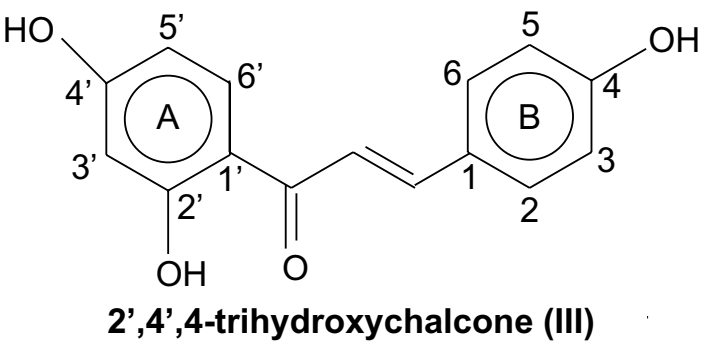

Figure 1. Structure of the flavonoids used in this study.

\begin{tabular}{|c|c|c|c|c|c|c|c|}
\hline \multirow{3}{*}{ I } & $\mathrm{C}$ & 0 & 25.35 & 32.96 & 40.56 & 45.63 & 50.70 \\
\hline & & & & & & & \\
\hline & $\mu \times 10^{3}$ & 50.0 & 39.83 & 37.86 & 32.73 & 30.51 & 29.07 \\
\hline \multirow{3}{*}{ II } & $\mathrm{C}$ & 0 & 12.30 & 21.54 & 24.61 & 27.70 & 30.77 \\
\hline & & & & & & & \\
\hline & $\mu \times 10^{3}$ & 50.0 & 45.61 & 40.60 & 41.31 & 36.78 & 35.57 \\
\hline \multirow{2}{*}{ III } & $\mathrm{C}$ & 0 & 10.53 & 14.74 & 21.00 & 27.38 & 33.00 \\
\hline & $\mu \times 10^{3}$ & 50.0 & 33.02 & 27.73 & 14.86 & 4.60 & 0 \\
\hline
\end{tabular}

Table 1. Specific growth rate of S. aureus ATCC 25923 as a function of the concentration of flavonoids I, II and III.

$\mathrm{C}$ : drug concentration $\left(\mu \mathrm{gml}^{-1}\right) ; \mu$ : specific growth rate $\left(\mathrm{min}^{-1}\right) ; \mathrm{I}$ : 5,7,4'-trihydroxyflavanone; II: 5,7-dihydroxyflavone and III: 2',4',4- trihydroxychalcone. 


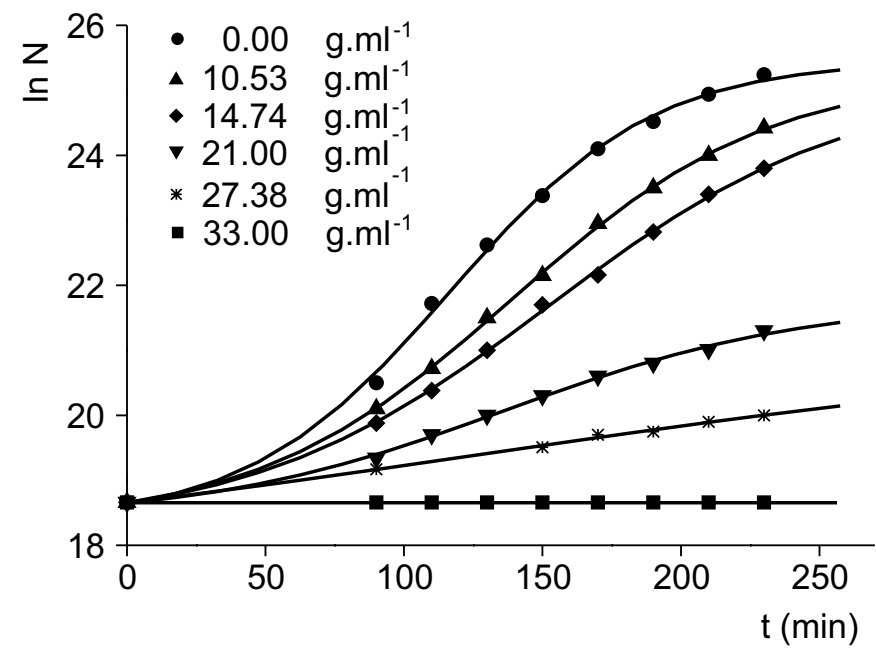

Figure 2. Growth of Staphylococcus aureus ATCC 25923 in media with 2',4',4-trihydroxychalcone.

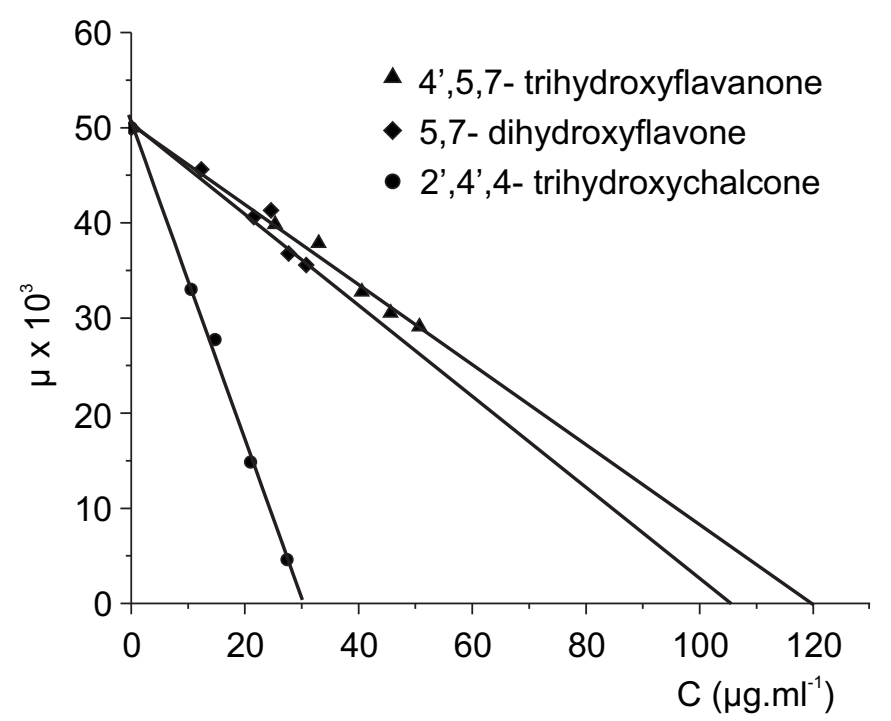

Figure 3. Graphical determination of MICs (minimal inhibitory concentrations) by extrapolation at the abcis when $\mu=0$.

The graphical representation of expression (3) is shown in Fig. 3 for the assayed compound and minimal inhibitory concentrations were evaluated by extrapolation at $\mu=0$.

Previous works $(11,12,13)$ described the original kineticturbidimetric procedure and reported that MICs of 2',4'dihydroxychalcone, flavanone and 7-hydroxyflavanone were $28.8 \mu \mathrm{gml}$ previously $197.6 \mu \mathrm{gml}^{-1}$, respectively.

The minimal inhibitory concentration values obtained for the compounds assayed in our study were as follows: $\mathrm{MIC}_{5,7,4^{-} \text {- }}$ trihydroxyflavanone $120 \mu \mathrm{gml}^{-1}>>>\mathrm{MIC}_{2}, 4,4$, -trihydroxychalcone $29 \mu \mathrm{gml}^{-1}$ and $\mathrm{MIC}_{5,7 \text {-dihydroxyflavone }} 105 \mu \mathrm{gml}^{-1}>>>\mathrm{MIC}_{2}, 4$-dihydroxychalcone $28.8 \mu \mathrm{gml}^{-1}$.
These results indicate that the chalcone structure is the most favourable for bacteriostatic activity within the flavonoid family.

Inhibition values were compared with other values previouly determined: $\mathrm{MIC}_{\text {flavanone }}$ inactive $>\mathrm{MIC}_{7 \text {-hydroxyflavanone }} 197.6 \mu \mathrm{gml}^{-1}$ $>\mathrm{MIC}_{5,7,4}$-trihydroxyflavanone $120 \mu \mathrm{gml}^{-1}$. This sequence clearly shows that the introduction of an electron donating group (-OH) increased the bioactivity of these compounds.

\section{ACKNOWLEDGEMENTS}

The present work was supported by the San Luis National University.

\section{RESUMO}

\section{Um estudo comparativo da atividade bacteriostática de flavonóides hidroxilados sintéticos}

Os flavonóides apresentam, entre outras, uma notável atividade bacteriostática. Neste trabalho determinaram-se as concentrações inibitórias mínimas de 5,7,4'-trihidroxiflavanona (naringenina), 5,7-dihidroxiflavona e 2',4',4-trihidroxichalcona (isoliquitirigenina) frente a Staphylococcus aureus ATCC 25 923 e comparadas com valores obtidos para outras chalconas e flavanonas investigadas previamente. As velocidades específicas de crescimento e as MICs foram avaliadas por um método cinéticoturbidimétrico. A sequência observada $\mathrm{MIC}_{\text {flavanona(inactiva) }}$ $>\mathrm{MIC}_{7 \text {-hidroxiflavanona }}\left(197,6 \mu \mathrm{gml}^{-1}\right)>\mathrm{MIC}_{5,7,4^{-} \text {-trihidroxiflavanona }}\left(120 \mu \mathrm{gml}^{-1}\right)$ mostrou que a introdução de um grupo doador de elétrons $(-\mathrm{OH})$ provoca um aumento da bioatividade. Por outro lado, $\operatorname{MIC}_{5,7,4^{4} \text {-trihidroxiflavanona }}\left(120 \mu \mathrm{g} \mathrm{ml}^{-1}\right)>>>\operatorname{MIC}_{2}, 4^{\prime}$, -trihididroxichalcona $(29$ $\left.\mu \mathrm{g} \mathrm{ml}^{-1}\right)$ e $\mathrm{MIC}_{5,7 \text {-dihidroxiflavona }}\left(105 \mu \mathrm{g} \mathrm{ml}^{-1}\right) \gg>\mathrm{MIC}_{2,4}$-4-dihidroxichalcona $\left(28,8 \mu \mathrm{g} \mathrm{ml}^{-1}\right)$ permitiram concluir que a estrutura chalcona é a mais favorável para a atividade bacteriostática dentro da família dos flavonóides.

Palavras-chave: flavanona, chalcona, atividade bacteriostática

\section{REFERENCES}

1. Baez, D.H.; Delosrios, C.; Crescente, O.; Caserta, A. Antibacterial and chemical evaluation of Chromolaena moritziana. J. Ethnopharmacol., 59:203-206, 1998

2. Benaventegarcia, O.; Castillo, J.; Marin, F.R.; Ortuno, A.; Delrio, J.A. Uses and properties of Citrus flavonoids., J.Agr.Food Chem., 45:4505-4515, 1997.

3. Chan, S.C.; Chang, Y.S.; Wang, J.P.; Chen, S.C.; Kuo, S.C. Three new flavonoids and antiallergic, anti-inflammatory constituents from the heartwood of Dalbergia odorifera. Planta Medica, 64:153-158, 1998.

4. Devia, C.M.; Pappano, N.B.; Debattista, N.B. Structure-Biological activity relationship of synthetic trihydroxylated chalcones. Rev. Microbiol., 29:307-310, 1998.

5. Dhar, D.N. The Chemistry of Chalcones and Related Compounds. John Wiley \& Sons, New York, 1981, p.5-9. 
6. Knet, P.; Jarvinen, R.; Seppanen, R.; Heliovaara, M.; Teppo, L.; Pukkada, E.; Aromaa, A. Dietary flavonoids and the risk of lung cancer and other malignant neoplasms. Am. J. Epidemiol., 146:223230, 1997.

7. Lin, J.K., Chen, Y.C.; Huang, Y.T.; Linshiau, S.Y. Supression of protein kinase $\mathrm{C}$ and nuclear oncogene expression as possible molecular mechanisms of cancer chemopre- prevention. $J$. Cell.Biochem., 28-29:39-48, 1997.

8. Lin, Y.M.; Zembower, D.E.; Flavin, M.T.; Schure, R.M.; Anderson, H.M.; Korba, B.E.; Chen F.C. Robustaflavone, a naturally ocurring biflavanoid, is a potent nonnucleoside inhibitor of hepatitis B virus replication in vitro. Bioorg. Medicinal Chem. Letter, 7:2325-2328, 1997.

9. Orallo, F.; Lamela, M.; Lamina, M.; Uriarte, E.; Calleja, J.M. Preliminary study of the potential vasodilator effects on rat aorta of centaurein and centaureidin, two flavonoids fron Centaurea corcubionensis, Planta Medica, 64:116-119, 1998.

10. Oyanagui, Y. Natural antioxidants enhance and prolong the oxyradical/NO- related suppression by dexametthasone of ischemic and histamine paw edema in mice. Inflammation, 21:643-654, 1997.
11. Pappano, N.B.; Blanco, S.E.; Debattista, N.B.; Segovia, R.F.; Ferretti, F.H. Mechanisms of bacteriostatic action of flavonoids on a Staphylococcus aureus strain. Com Biol (Bs Aires), 4:23-38, 1985.

12. Pappano, N.B.; Centorbi, O.P.; Debattista, N.B.; Milán, C.C.; Borkowski, E.J.; Ferretti, F.H. Cinética de la acción bacteriostática de chalconas naturales y de síntesis sobre una cepa de Staphylococcus aureus. Rev. Argent. Microbiol., 17:27-32, 1985.

13. Pappano, N.B.; Centorbi, O.P.; Ferretti, F.H. Determinación de la concentración inhibitoria mínima a partir de parámetros cinéticos de crecimiento. Rev. Microbiol., 21:183-188, 1990.

14. Pappano, N.B.; Centorbi, O.P.; Ferretti, F.H. Determination of the responsible molecular zone for the chalcones bacteriostatic activity. Rev. Microbiol., 25:168-174, 1994.

15. Pérez, R.M.; Zavala, M.A.; Pérez, S.; Pérez, C. Antidiabetic effect of compounds isolated from plants. Phytomedicine, 5:55-75, 1998

16. Sarma, A.D.; Sreelakshmi, Y.; Sharma, R. Antioxidant ability of anthocyanins against ascorbic acid oxidation. Phytochemistry, 45:671-674, 1997.

17. Tereschuk, M.L.; Riera, M.V.Q.; Castro, G.R.; Abdala, L.R. Antimicrobial activity of flavonoids from leaves of Tagetes minuta. J. Ethnopharmacol., 56:227-232, 1997. 